\title{
TUNGSTEN AND RHENIUM AS HYDROGENATION AGENTS IN THE HYDRODENITROGENATION OF PYRIDINE USING STACKED BED CATALYST SYSTEMS
}

\author{
R. BASSI ${ }^{a}$, M. VILLARROEL ${ }^{a *}$, F.J. GIL LLAMBÍAS ${ }^{a}$, E. CAMÚb, P. BAEZA ${ }^{b}$. \\ a: Universidad de Santiago, Facultad de Química y Biología, Casilla 40, Correo 33, Santiago, Chile.

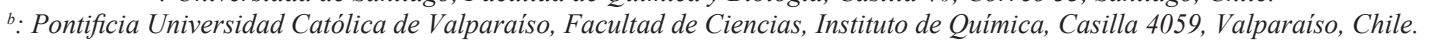

\begin{abstract}
This study analyses the hydrodenitrogenation (HDN) of pyridine using a stacked bed catalyst system, composed of a first hydrogenating bed of $\mathrm{Re} / \mathrm{Al}_{2} \mathrm{O}_{3}$ or $\mathrm{W} / \gamma-\mathrm{Al}_{2} \mathrm{O}_{3}$, over a second bed of Ni-Re/ $\gamma-\mathrm{Al}_{2} \mathrm{O}_{3}$ (HDN bed). Using potentiometric methods, it can be seen that the Re/ $\gamma$ - $\mathrm{Al}_{2} \mathrm{O}_{3}$ shows higher acidic strength than the $\mathrm{W} / \gamma-\mathrm{Al}_{2} \mathrm{O}_{3}$. The results show that higher activity levels are obtained working with stacked bed systems compared to the separate catalysts. These results suggest that the incorporation of the catalyst $\mathrm{Re} / \gamma-\mathrm{Al}_{2} \mathrm{O}_{3}$ or $\mathrm{W} / \gamma-\mathrm{Al}_{2} \mathrm{O}_{3}$ beds would favour the formation of hydrogenated intermediary products, facilitating the removal of $\mathrm{N}$-containing molecules via $\mathrm{HDN}$ on the $\mathrm{Ni}-\mathrm{Re} / \gamma-\mathrm{Al}_{2} \mathrm{O}_{3}$ catalyst.
\end{abstract}

Keywords: Hydrodenitrogenation (HDN); Hydrogenation; Stacked beds; Pyridine.

\section{INTRODUCTION}

In recent years, several different reports have shown that petroleum will continue to be one of the main energy sources until the year 2030 and that the global energy system will continue to be dominated by fossil fuels ${ }^{1}$. However, as the high demand for petroleum is unavoidable, deeper search and exploitation of oil fields, obtaining heavier crude oil as a result, will lead to more difficult purification processes, particularly hydrotreatment (HT) processes. These processes contribute to decreasing atmospheric pollution caused by the combustion of petroleum and its derivatives. In addition, environmental regulations have forced the oil industry to reduce nitrogen and sulphur levels in fuels. In order to comply with these demands, is fundamental to find more active catalysts for HT processes than the classic $\mathrm{Co}-\mathrm{Mo} / \gamma-\mathrm{Al}_{2} \mathrm{O}_{3}{ }^{1}$ one. Specifically, one HT process, namely hydrodenitrogenation (HDN), has been the focus of study in recent years ${ }^{2-6}$, as many $\mathrm{N}$-containing compounds that are resistant to HDN are present in petroleum, and mainly because these molecules inhibit hydrodesulphurisation (HDS) and other HT reactions $\mathrm{s}^{7-9}$ due to preferential adsorption of such $\mathrm{N}$-containing molecules on catalytic sites. Laredo et al. ${ }^{10}$ evaluated the inhibiting effect of nitrogenised compounds on the HDS of dibenzothiophene (DBT), reporting that the inhibiting effect of non-base nitrogen on indole and carbazole compounds in the HDS of DBT is comparable to that of base nitrogen compounds, such as quinoline. The inhibiting effect of these compounds is very strong, even at low concentrations close to $5 \mathrm{ppm}$ of nitrogen. As a result, it is necessary to implement new catalyst systems that offer improved activity and selectivity for HDN. Therefore, in order to study HDN, different model molecules have been used ${ }^{11-14}$, one of which is pyridine ${ }^{15-17}$. Valdebenito et al. ${ }^{17}$ worked with stacked bed systems in the HDN of pyridine, proving that it is possible to achieve this process through the formation of hydrogen spillover (Hso), generating an effect similar to that observed for the HDS reaction ${ }^{18-23}$. This proposal is based on prior work by Ojeda et al. ${ }^{24}$, who give direct proof of the hydrogen spillover effect, under conditions similar to those used in industry, and using gas oil as the feed source. This study reported the existence of synergism in the stacked bed systems of $\mathrm{Co} / \mathrm{SiO}_{2} / / \mathrm{SiO}_{2} / / \mathrm{Mo} / \mathrm{SiO}_{2}$ (donor//separator//acceptor), where the donor and the acceptor were separated using the amount of $\mathrm{SiO}_{2}$ needed to create a distance of $5 \mathrm{~mm}$ between the two beds. Under these conditions the synergism is determined only by the remote control model, via Hso, as there is no possibility of the formation of the Co-Mo-S phase.

Several studies have been carried out into the mechanism of the HDN of pyridine. Mcllvried et al. ${ }^{25}$ reported that the reaction is composed of three successive stages: hydrogenation of the pyridine ring, hydrogenolysis of the $\mathrm{C}-\mathrm{N}$ bond forming pentylamine and denitrogenation to give the end products pentane and ammonia, where the hydrogenation is an essential step for achieving nitrogen removal. Anabtawi et al. ${ }^{26}$ used an integral flow reactor to study the hydrogenation of pyridine in gaseous phase, using $\mathrm{Ni}-\mathrm{W} / \gamma-\mathrm{Al}_{2} \mathrm{O}_{3}$ as catalyst, finding that pyridine hydrogenation follows three stages. The first is saturation of the double bond of the pyridine to form piperidine, the second is disproportionation of the pyridine to produce ammonia and n-pentylpiperidine, and the third is the formation of n-pentane from the pentylpiperidine.

Considering that hydrogenation is one of the most important steps in the conversion of N-containing molecules, and that the hydrogenating properties of tungsten and rhenium have been proven in hydrotreatment reactions ${ }^{27}$, the objective of the present study was to analyse the HDN reaction of pyridine in a stacked bed system composed of a first hydrogenating bed over a second HDN bed.

\section{MATERIALS AND METHODS}

2.1 Preparation of catalysts

All the catalysts were prepared as reported previouly ${ }^{18-23}$, using excess solvent impregnation for monometallic catalysts $\left(\mathrm{Re} / \gamma-\mathrm{Al}_{2} \mathrm{O}_{3}\right.$ or $\left.\mathrm{W} / \gamma-\mathrm{Al}_{2} \mathrm{O}_{3}\right)$ and successive impregnation for bimetallic catalysts $\left(\mathrm{Ni}-\mathrm{Re} / \gamma-\mathrm{Al}_{2} \mathrm{O}_{3}\right.$ or $\mathrm{Ni}-\mathrm{Mo} /$ $\left.\gamma-\mathrm{Al}_{2} \mathrm{O}_{3}\right)$. As precursor salts, $\mathrm{NH}_{4} \mathrm{ReO}_{4}$ (Aldrich), $\left(\mathrm{NH}_{4}\right)_{6} \mathrm{MoO}_{24} \mathrm{x}^{4} \mathrm{H}_{2} \mathrm{O}$ (Merck pa.) and $\left(\mathrm{NH}_{4}\right)_{10} \mathrm{~W}_{12} \mathrm{O}_{41} \times 5 \mathrm{H}_{2} \mathrm{O}$ (BDH Chemicals Ltda.) were used respectively. $\mathrm{Ni}$ was used as promoter, and was prepared from $\mathrm{Ni}\left(\mathrm{NO}_{3}\right)_{2} \times 6 \mathrm{H}_{2} \mathrm{O}$ (Merck pa.). The support for all catalysts was $\gamma-\mathrm{Al}_{2} \mathrm{O}_{3}$, BASF D10-10 $\left(\mathrm{N}_{2}\right.$ BET $\left.212 \mathrm{~m}^{2} \mathrm{~g}^{-1}\right)$ with a particle size of 0.84 and $1.19 \mathrm{~mm}$. The nominal metal content of the precursors was $0.5,1.5$ and 3.0 atoms $\mathrm{nm}^{-2}$ for the monometallic catalysts while for bimetallic catalysts, 1.6 atoms nm-2 $\mathrm{Ni}, 2.9$ atoms $\mathrm{nm}^{-2}$ Mo and 0.5 atoms $\mathrm{nm}^{-2} \mathrm{Re}$ were used. After metal impregnation, the samples were dried at $373 \mathrm{~K}$ for $12 \mathrm{~h}$. Subsequently, the impregnated samples with $\mathrm{W}$ or Mo were calcined at $823 \mathrm{~K}$ for 4.5 hours, while the Re catalyst was calcined at $573 \mathrm{~K}$ for $0.5 \mathrm{~h}$.

2.2 Reaction conditions

Prior to carrying out the HDN of pyridine, each system (single and stacked bed) was in situ sulphided using a gas mixture of $10 \% \mathrm{H}_{2} \mathrm{~S} / \mathrm{N}_{2}$ at atmospheric pressure and $623 \mathrm{~K}$ for $4 \mathrm{~h}$.

Catalytic activity was measured as reported previously ${ }^{18-23}$ using a stainless steel continuous-flow micro-reactor under conditions similar to those used in industry. Total $\mathrm{H}_{2}$ pressure was $3 \mathrm{MPa}$ and the reaction temperatures were 573,598 and $623 \mathrm{~K}$. The feed solution was a synthetic mixture of $5000 \mathrm{ppmv}$ pyridine in decalin at a flow rate of $30 \mathrm{~mL} \mathrm{~min}{ }^{-1}$. The reactor was loaded as shown in Figure 1. For single beds, it was loaded with $1 \mathrm{~g}$ of catalysts $(\mathrm{Ni}-\mathrm{Re} / \gamma$ $\mathrm{Al}_{2} \mathrm{O}, \mathrm{Ni}-\mathrm{Mo} / \gamma-\mathrm{Al} \mathrm{O}_{2}, \mathrm{Re} / \gamma-\mathrm{Al}_{2} \mathrm{O}$ or $\mathrm{W} / \gamma-\mathrm{Al}_{2} \mathrm{O}$ ) and for stacked beds, $0.5 \mathrm{~g}$ of catalyst was loaded onto each of the beds, such that the hydrogenating bed (Re/ $\gamma-\mathrm{Al}_{2} \mathrm{O}_{3}$ or $\left.\mathrm{W} / \gamma-\mathrm{Al}_{2} \mathrm{O}_{3}\right)$ was above the $\mathrm{HDN}$ bed $\left(\mathrm{Ni}-\mathrm{Re} / \gamma-\mathrm{Al}_{2} \mathrm{O}_{3}\right)$, the stacked bed are represented as HYD bed//HDN bed. As in previous studies ${ }^{18-23}$ beds were diluted with $\mathrm{SiO}_{2}$ (BASF D11-10) at a $\mathrm{v} / \mathrm{v}$ ratio of 1:1, and the remainder of the reactor was filled with $\mathrm{SiC}$.

Under these conditions, four samples were taken every $30 \mathrm{~min}$. The first and second were discarded and the third and fourth were analysed using GCFID. After obtaining the fourth sample, the system temperature was lowered and the same sampling process was carried out for each reaction temperature. 

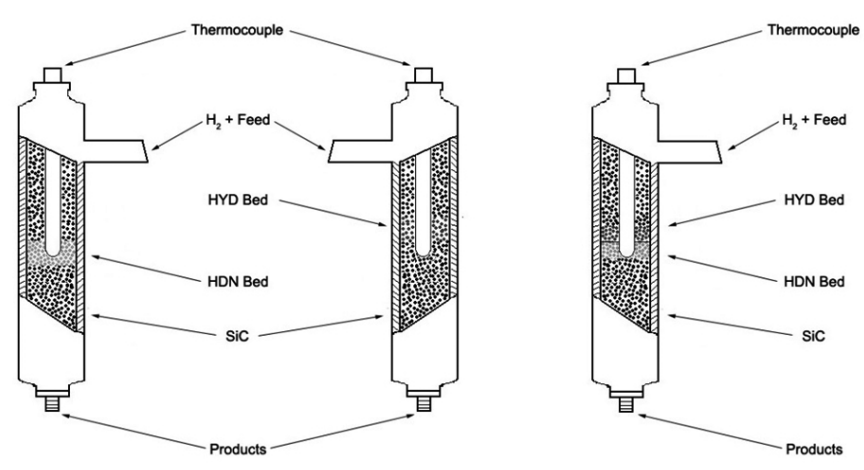

Figure 1. Scheme of reactor loading in single bed (left) and stacked bed (right).

\subsection{Activity measurements}

The reaction products were identified by measuring the samples in a gas chromatograph provided with a flame ionization detector. The equipment used was a SHIMADZU GC-2010 model, with a SPB-5 column measuring $30 \mathrm{~m}$ in length, with a thickness of $0.25 \mathrm{~mm}$ and a film of $0.25 \mu \mathrm{m}, 0.5 \mu \mathrm{L}$ sample injections with an autosampler. The heating procedure was initiated, maintaining the column temperature at $333 \mathrm{~K}$ for $5 \mathrm{~min}$. It was then increased to $373 \mathrm{~K}$ at a rate of $288 \mathrm{~K} \mathrm{~min}^{-1}$ and maintained at this temperature for 8 min. Finally, the temperature was increased to $473 \mathrm{~K}$ at a rate of $323 \mathrm{~K} \mathrm{~min}^{-1}$, and maintained at this temperature for $2 \mathrm{~min}$. The molecules present in the samples were identified by doping the feed with standard molecules of possible products that are expected from this catalytic reaction.

\section{RESULTS AND DISCUSSION}

3.1 Characterisation of monometallic catalysts

Optical emission spectroscopy with inductively coupled plasma (ICP) was used to determine the real metal content of the catalysts after preparation from the respective precursor salts. As can be seen in Table 1, there is close association between the nominal metal content and the real metal content by ICP.

Table 1. Metal content (determined by ICP) of the catalysts.

\begin{tabular}{|c|c|c|}
\hline Catalyst & $\begin{array}{l}\text { Theoretical loading } \\
\text { (atoms } \mathbf{n m}^{-2} \text { ) }\end{array}$ & $\begin{array}{l}\text { Measured loading } \\
\text { (atoms } \mathbf{n m}^{-2} \text { ) }\end{array}$ \\
\hline $\mathrm{W}(0.5) / \gamma-\mathrm{Al}_{2} \mathrm{O}_{3}$ & 0.50 & 0.47 \\
\hline $\mathrm{W}(1.5) / \gamma-\mathrm{Al}_{2} \mathrm{O}_{3}$ & 1.50 & 1.41 \\
\hline $\mathbf{W}(\mathbf{3 . 0}) / \gamma-\mathrm{Al}_{2} \mathrm{O}_{3}$ & 3.00 & 2.67 \\
\hline $\operatorname{Re}(0.5) / \gamma-\mathrm{Al}_{2} \mathrm{O}_{3}$ & 0.50 & 0.44 \\
\hline $\operatorname{Re}(1.5) / \gamma-\mathrm{Al}_{2} \mathrm{O}_{3}$ & 1.50 & 1.43 \\
\hline $\operatorname{Re}(3.0) / \gamma-\mathrm{Al}_{2} \mathrm{O}_{3}$ & 3.00 & 2.69 \\
\hline
\end{tabular}

The acidity of the surface of the oxidised catalysts was determined by potentiometric evaluation with n-butylamine in acetonitrile using an $\mathrm{Ag} / \mathrm{AgCl}$ electrode, in accordance with a procedure described previously ${ }^{28}$. Figure 2 shows the acid strength results, in which it can be seen that in the studied range of metallic content the $\mathrm{Re} / \gamma-\mathrm{Al}_{2} \mathrm{O}_{3}$ catalyst shows higher acid strength than the $\mathrm{W} / \gamma-\mathrm{Al}_{2} \mathrm{O}_{3}$ one. This is because the $\mathrm{Re} / \gamma-\mathrm{Al}_{2} \mathrm{O}_{3}$ has a greater capacity for converting a base into its acid conjugate than the $\mathrm{W} / \gamma-\mathrm{Al}_{2} \mathrm{O}_{3}$ one.

Therefore, it can be concluded that these catalysts have metal loadings in agreement with the nominal values and that both the tungsten and the rhenium catalysts supported on $\gamma-\mathrm{Al}_{2} \mathrm{O}_{3}$ are acidic. Indeed, acidity can play a crucial role in the adsorption of nitrogenised molecules ${ }^{29}$, thus facilitating pyridine conversion.

3.2 Sample analysis and activity results

Figure 3 shows a section of the chromatogram obtained after the HDN of pyridine using Ni-Re $/ \gamma-\mathrm{Al}_{2} \mathrm{O}_{3}$ as catalyst. With the use of a standard, the identified molecules were pentylamine and pentane as the hydrogenation and HDN products at retention times 1.15 and $1.60 \mathrm{~min}$, respectively. The unreacted pyridine was observed at retention time $1.90 \mathrm{~min}$. These products are in agreement with the reaction mechanism proposed by McIlvierd et al. ${ }^{25}$ (Figure 4), who stated that to obtain the above reaction products, piperidine must be first formed. However, piperidine was not detected in the present study, as this molecule is very unstable. Once it is formed, and converted rapidly to pentylamine or pyridine.

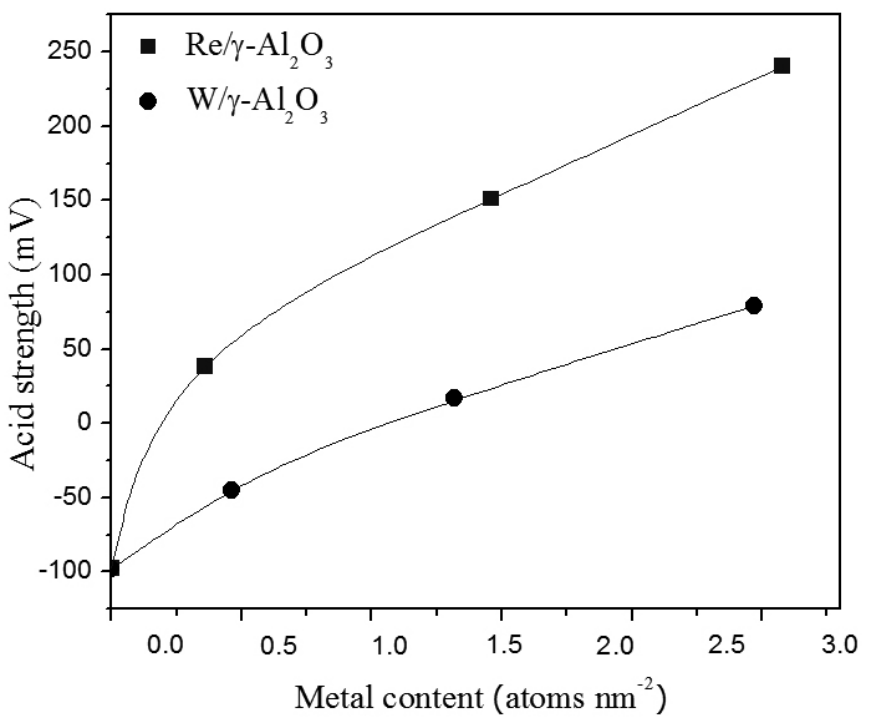

Figure 2. Acid strength of the catalysts $\mathrm{W}(\mathrm{x}) / \gamma-\mathrm{Al}_{2} \mathrm{O}_{3}$ and $\mathrm{Re}(\mathrm{x}) / \gamma-\mathrm{Al}_{2} \mathrm{O}_{3}$.

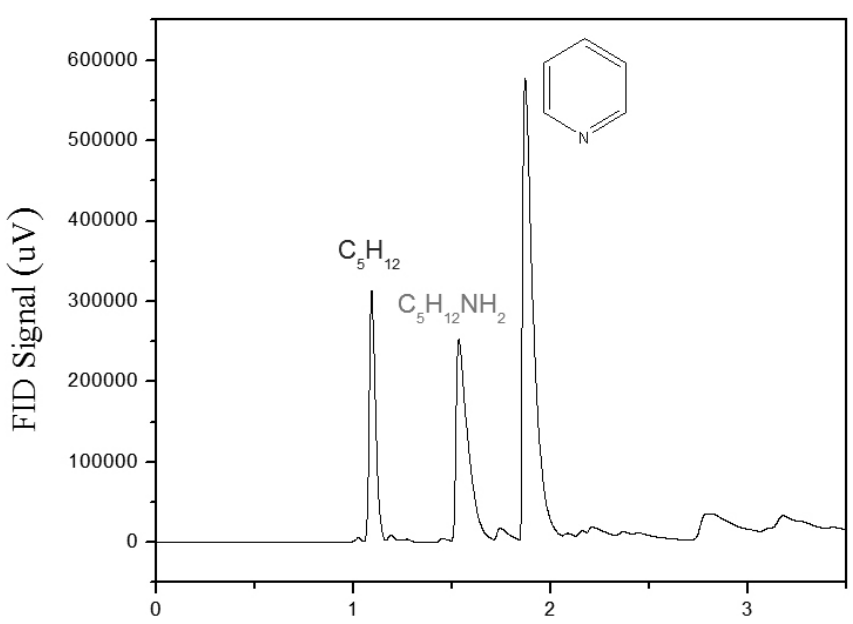

Time (min)

Figure 3. Chromatogram obtained after HDN of pyridine using $\mathrm{Ni}-\mathrm{Re} / \gamma$ $\mathrm{Al}_{2} \mathrm{O}_{3}$ as catalyst.

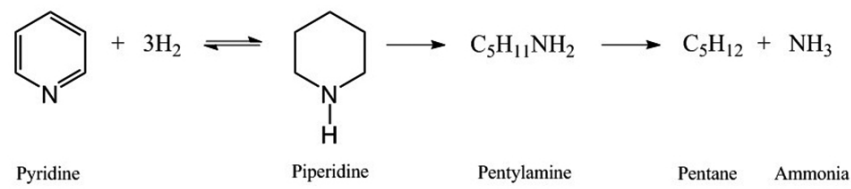

Figure 4. Reaction mechanism for the HDN of pyridine ${ }^{25}$.

In order to determine the effect of intercalation of a hydrogenating bed over the HDN catalyst it was necessary to evaluate the conversion and selectivity of each catalyst in a single bed system and then evaluate the same parameters in a stacked bed system.

The extent of pyridine HDN reaction was evaluated for each catalytic system by measuring pyridine concentration at the inlet and exit of the reactor. These results are reported in Table 2 as pyridine conversion (Py) and formation 
of reaction products, were calculated as follows: \% Py conversion: $\left(\left(\mathrm{Py}_{0}-\mathrm{Py} y_{\mathrm{m}}\right) /\right.$ $\mathrm{Py}_{\mathrm{o}} * 100$ and \% product formation: $(\mathrm{Pe}(\mathrm{Pa}) / \mathrm{P}) * 100$, where $\mathrm{Py}_{\mathrm{o}}$ is the area of the pyridine chromatogram peak seen in the feed, $\mathrm{Py}_{\mathrm{m}}$ is the area of the pyridine after the catalytic reaction, $\mathrm{Pe}$ is the area of pentane, $\mathrm{Pa}$ is the area of the pentylamine and $\mathrm{P}$ is the sum of the area of the reaction products.

Table 2 shows the pyridine conversion percentages and the relative product formation percentages for the monometallic catalysts, $\mathrm{Re} / \gamma-\mathrm{Al}_{2} \mathrm{O}_{3}$ and $\mathrm{W} / \gamma-\mathrm{Al}_{2} \mathrm{O}_{3}$, and for the bimetallic $\mathrm{Ni}-\mathrm{Re} / \gamma-\mathrm{Al}_{2} \mathrm{O}_{3}$ and $\mathrm{Ni}-\mathrm{Mo} / \gamma-\mathrm{Al}_{2} \mathrm{O}_{3}$ catalysts. Initially, the performance of the monometallic catalysts was evaluated. Table 2 shows the effect of the metal content of the $\mathrm{Re}(\mathrm{x}) / \gamma-\mathrm{Al}_{2} \mathrm{O}_{3}$ and $\mathrm{W}(\mathrm{x}) / \gamma-\mathrm{Al}_{2} \mathrm{O}_{3}$ in the intercalated catalysts beds on pyridine conversion. Table 2 shows that as the metal content increases, higher pyridine conversion rates are obtained. This behaviour is displayed for both catalysts. It can also be seen that for all metal loadings, the rhenium has higher pyridine conversion rates than tungsten. This result is in line with the acid strength data shown in Figure 1 which indicate that $\operatorname{Re}(\mathrm{x}) / \gamma-\mathrm{Al}_{2} \mathrm{O}_{3}$ catalysts presented a higher number of acidic sites. The reaction products formed using these catalysts at different metal content levels are shown in Table 2. In these cases, the HDN reaction proceeds were pentane and pentylamine. Comparing the two catalysts, it can be stated that the $\operatorname{Re}(\mathrm{x}) / \gamma$ $\mathrm{Al}_{2} \mathrm{O}_{3}$ catalyst favours hydrogenation as confirmed by the greater formation of pentylamine, because the $\mathrm{Re} / \gamma-\mathrm{Al}_{2} \mathrm{O}_{3}$ catalyst has high hydrogenating properties $^{27}$. Based on these findings, it was interesting to see what happens when using $\mathrm{Re} / \gamma-\mathrm{Al}_{2} \mathrm{O}_{3}$ as the upper bed in the stacked bed system.

It is also important to evaluate the results obtained for the bimetallic catalysts. In Table 2 it can be seen that for the Ni-Re $/ \gamma-\mathrm{Al}_{2} \mathrm{O}_{3}$ catalyst the pyridine conversions at all temperatures are higher than those obtained with the $\mathrm{Ni}-\mathrm{Mo} / \gamma-\mathrm{Al}_{2} \mathrm{O}_{3}$ one. This is interesting, because the $\mathrm{Ni}-\mathrm{Mo} / \gamma-\mathrm{Al}_{2} \mathrm{O}_{3}$ catalyst is the most commonly used system in petroleum hydrotreatment. It is also necessary to evaluate what happens with the reaction products for each catalyst system. The data collected in Table 2 show that the Ni-Mo/ $\gamma-\mathrm{Al}_{2} \mathrm{O}_{3}$ catalysts favours pentane formation, while for the $\mathrm{Ni}-\mathrm{Re} / \gamma-\mathrm{Al}_{2} \mathrm{O}_{3}$ system, both pentane and pentylamine are formed. The formation of pentylamine is in line with the products observed for the $\mathrm{Re} / \gamma-\mathrm{Al}_{2} \mathrm{O}_{3}$ catalyst, because rhenium favours pyridine hydrogenation to a greater extent. Considering that $\mathrm{Ni}-\mathrm{Re} / \gamma-\mathrm{Al}_{2} \mathrm{O}_{3}$ is more active than the conventional Ni-Mo one, it was then of interest to use Ni$\mathrm{Re} / \gamma-\mathrm{Al}_{2} \mathrm{O}_{3}$ as the lower bed in the stacked bed catalyst systems.

Table 2: Conversion of pyridine and formation of reaction products at $623 \mathrm{~K}$.

\begin{tabular}{|c|c|c|c|}
\hline \multirow{2}{*}{ Bed } & \multirow{2}{*}{$\begin{array}{l}\text { Pyridine } \\
\text { Conversion } \\
(\%)\end{array}$} & \multicolumn{2}{|c|}{$\begin{array}{l}\text { Relative Products } \\
\text { Conversion (\%) }\end{array}$} \\
\hline & & Pentylamine & Pentane \\
\hline $\mathrm{Ni}(1.6)-\mathrm{Mo}(2.9) / \gamma-\mathrm{Al}_{2} \mathrm{O}_{3}$ & 37.7 & 0.0 & 100 \\
\hline $\mathrm{Ni}(1.6)-\operatorname{Re}(0.5) / \gamma-\mathrm{Al}_{2} \mathrm{O}_{3}$ & 63.7 & 15.8 & 84.2 \\
\hline $\mathrm{W}(0.5) / \gamma-\mathrm{Al}_{2} \mathrm{O}_{3}$ & 55.7 & 36.9 & 63.1 \\
\hline $\mathrm{W}(1.5) / \gamma-\mathrm{Al}_{2} \mathrm{O}_{3}$ & 57.2 & 24.3 & 75.7 \\
\hline $\mathrm{W}(3.0) / \gamma-\mathrm{Al}_{2} \mathrm{O}_{3}$ & 67.0 & 23.5 & 76.5 \\
\hline $\operatorname{Re}(0.5) / \gamma-\mathrm{Al}_{2} \mathrm{O}_{3}$ & 60.8 & 50.7 & 49.3 \\
\hline $\operatorname{Re}(1.5) / \gamma-\mathrm{Al}_{2} \mathrm{O}_{3}$ & 70.5 & 55.7 & 44.3 \\
\hline $\operatorname{Re}(3.0) / \gamma-\mathrm{Al}_{2} \mathrm{O}_{3}$ & 81.1 & 73.3 & 26.7 \\
\hline
\end{tabular}

Based on the results described in Table 2, $\mathrm{Re} / \gamma-\mathrm{Al}_{2} \mathrm{O}_{3}$ catalyst was selected as the hydrogenating bed over the catalyst $\mathrm{Ni}-\mathrm{Re} / \gamma-\mathrm{Al}_{2} \mathrm{O}_{3}$, forming a stacked bed catalyst system. The $\mathrm{Re} / \gamma-\mathrm{Al}_{2} \mathrm{O}_{3}$ catalyst selected for this system showed

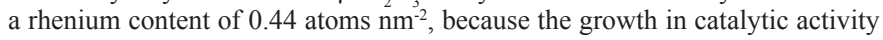
above Re loadings of 0.44 atoms $\mathrm{nm}^{-2}$ is no longer linear, and it is therefore not economically viable to use higher rhenium content levels.

Another observation that can be made from the data collected in Table 2 is that the pentane formation of $\mathrm{Ni}-\mathrm{Re} / \gamma-\mathrm{Al}_{2} \mathrm{O}_{3}$ catalyst is higher than for the $\mathrm{Re}(0.44) / \gamma-\mathrm{Al}_{2} \mathrm{O}_{3}$ one, which is expected because in the bimetallic $\mathrm{Ni}-\operatorname{Re}(0.44) /$ $\gamma-\mathrm{Al}_{2} \mathrm{O}_{3}$ catalyst the $\mathrm{Ni}$ promotes the catalytic activity of $\mathrm{Re}^{23}$.

Figure 5 represents the pyridine conversions at three temperatures, with the following contents within the reactor:

i) Only the catalyst $\mathrm{Re} / \gamma-\mathrm{Al}_{2} \mathrm{O}_{3}$, the mass of $\mathrm{Ni}-\mathrm{Re} / \gamma-\mathrm{Al}_{2} \mathrm{O}_{3}$ is $0.0 \mathrm{~g}$,

ii) Only the catalyst $\mathrm{Ni}-\mathrm{Re} / \gamma-\mathrm{Al}_{2} \mathrm{O}_{3}$, the mass of $\mathrm{Ni}-\mathrm{Re} / \gamma-\mathrm{Al} \mathrm{l}_{2} \mathrm{O}_{3}$ is 1.0 $\mathrm{g}$, and

iii) Stacked beds of $\mathrm{Re} / \gamma-\mathrm{Al}_{2} \mathrm{O}_{3} / \mathrm{Ni}-\mathrm{Re} / \gamma-\mathrm{Al}_{2} \mathrm{O}_{3}$, the mass of Ni-Re/ $\gamma$ $\mathrm{Al}_{2} \mathrm{O}_{3}$ is $0.5 \mathrm{~g}$.
It is important to note that the total mass of the catalyst(s) within the reactor was maintained constant at $1.0 \mathrm{~g}$, and therefore if there was no synergism between the two beds $\left(\mathrm{Re} / \gamma-\mathrm{Al}_{2} \mathrm{O}_{3}\right.$ and $\left.\mathrm{Ni}-\mathrm{Re} / \gamma-\mathrm{Al}_{2} \mathrm{O}_{3}\right)$ they would have the same level of activity as the sum of their separate characteristics, which is shown by the dotted line.

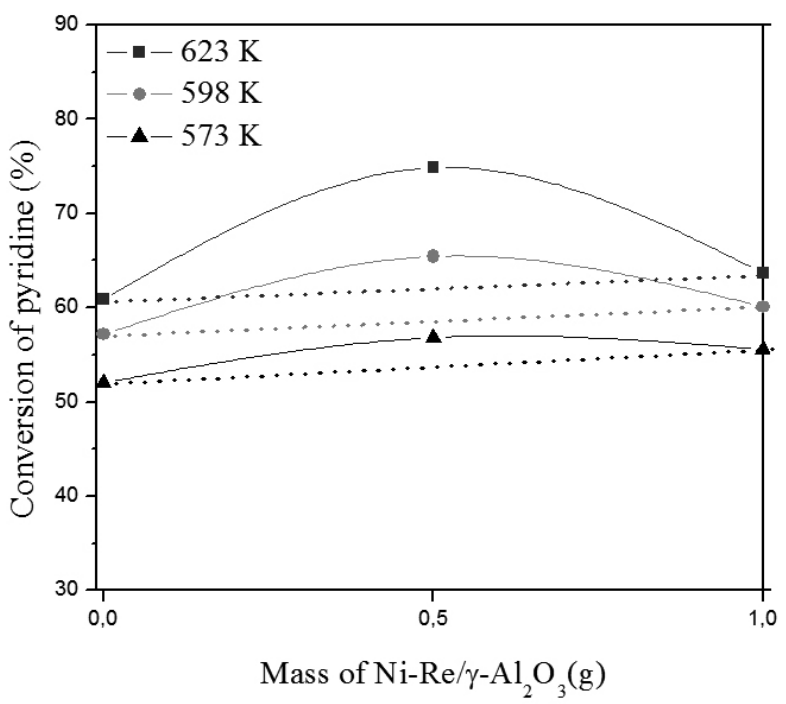

Figure 5. Conversion percentage of pyridine in $\mathrm{Re}(0.44) / \gamma-\mathrm{Al}_{2} \mathrm{O}_{3}, \mathrm{Ni}-\mathrm{Re} /$ $\gamma-\mathrm{Al}_{2} \mathrm{O}_{3}$ singles beds and $\mathrm{Re}(0.44) / \gamma-\mathrm{Al}_{2} \mathrm{O}_{3} / / \mathrm{Ni}-\mathrm{Re} / \gamma-\mathrm{Al}_{2} \mathrm{O}_{3}$ stacked bed system.

Figure 5 shows that the activity of the stacked beds is greater than the simple beds, as they give a higher value than the corresponding sum shown by the dotted line. Therefore, it is possible to state that the intercalation of a hydrogenating rhenium bed favours pyridine conversion of the catalyst Ni$\mathrm{Re} / \gamma-\mathrm{Al}_{2} \mathrm{O}_{3}$.

It is also interesting to know which reaction products are formed, in order to establish whether it is possible to favour the conversion of the products of the $\mathrm{HDN}$ of pyridine, i.e. pentane. Figure 6 shows the pentane formation results for the stacked bed system $\operatorname{Re}(0.44) / \gamma-\mathrm{Al}_{2} \mathrm{O}_{2} / \mathrm{Ni}-\mathrm{Re} / \gamma-\mathrm{Al}_{2} \mathrm{O}_{3}$. It can be seen that the use of a hydrogenating catalyst over $\mathrm{Ni}-\mathrm{Re} / \gamma-\mathrm{Al}_{2} \mathrm{O}_{3}$ favours the formation of pentane, as the pentane formation percentages for the stacked beds are higher than those obtained for the single beds at all working temperatures. This is probably due to the fact that the $\operatorname{Re}(0.44) / \gamma-\mathrm{Al}_{2} \mathrm{O}_{3}$ favours the formation of intermediate pentylamine which facilitates the removal of nitrogen in the catalyst $\mathrm{Ni}-\mathrm{Re} / \gamma-\mathrm{Al}_{2} \mathrm{O}_{3}$, thus obtaining higher pentane formation levels.

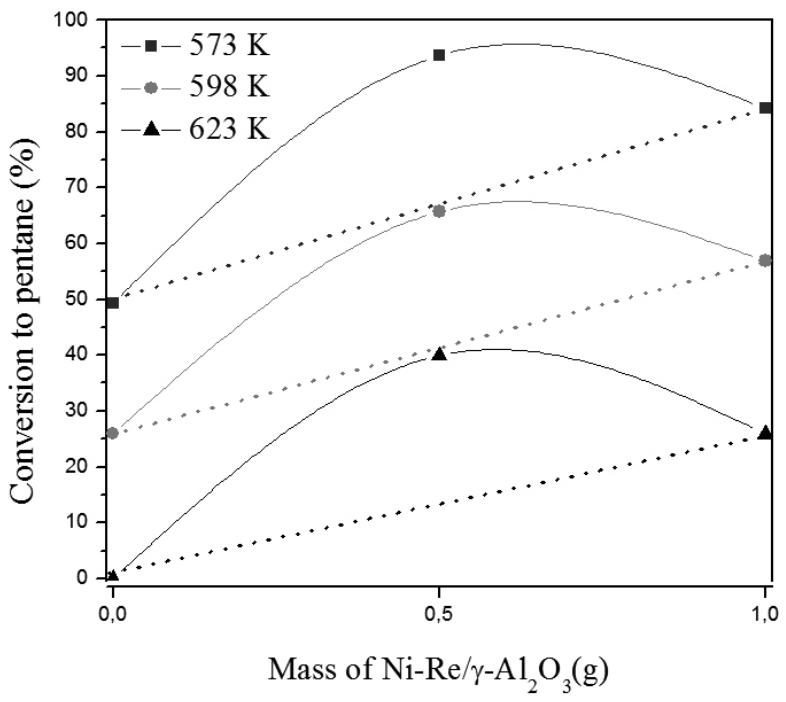

Figure 6. Conversion percentage to pentane in $\operatorname{Re}(0.44) / \gamma-\mathrm{Al}_{2} \mathrm{O}_{3}, \mathrm{Ni}-\mathrm{Re} / \gamma$ $\mathrm{Al}_{2} \mathrm{O}_{3}$ singles beds and $\mathrm{Re}(0.44) / \gamma-\mathrm{Al}_{2} \mathrm{O}_{3} / / \mathrm{Ni}-\mathrm{Re} / \gamma-\mathrm{Al}_{2} \mathrm{O}_{3}$ stacked bed system. 


\section{CONCLUSIONS}

The study of $\mathrm{Ni}-\mathrm{Re} / \gamma-\mathrm{Al}_{2} \mathrm{O}_{3}$ and $\mathrm{Ni}-\mathrm{Mo} / \gamma-\mathrm{Al}_{2} \mathrm{O}_{3}$ catalysts shows that the $\mathrm{Ni}-\mathrm{Re} / \gamma-\mathrm{Al}_{2} \mathrm{O}_{3}$ one gives higher levels of pyridine conversion, yielding pentane and pentylamine as end products. This result emphasizes the hydrogenating properties of rhenium, which is a fundamental step in the HDN of pyridine. The catalyst $\mathrm{Ni}-\mathrm{Mo} / \gamma-\mathrm{Al}_{2} \mathrm{O}_{3}$ shows lower pyridine conversion levels, however it does achieve pyridine conversion exclusively to pentane.

The study shows that both $\mathrm{Re} / \gamma-\mathrm{Al}_{2} \mathrm{O}_{3}$ and $\mathrm{W} / \gamma-\mathrm{Al}_{2} \mathrm{O}_{3}$ catalysts favour pyridine hydrogenation, the $\mathrm{Re} / \gamma-\mathrm{Al}_{2} \mathrm{O}_{3}$ shows more activity and a higher hydrogenating capacity than $\mathrm{W} / \gamma-\mathrm{Al}_{2}^{2} \mathrm{O}_{3}$. Finally, the study conducted using stacked bed catalyst systems clearly shows that the $\mathrm{Re} / \gamma-\mathrm{Al}_{2} \mathrm{O}_{3}$ bed favours the hydrogenation of pyridine, facilitating catalyst $\mathrm{Ni}-\mathrm{Re} / \gamma-\mathrm{Al}_{2} \mathrm{O}_{3}$ the elimination of nitrogen.

\section{ACKNOWLEDGMENTS}

This work has been financed under FONDECYT project 1130749.

\section{REFERENCES}

1. Y. Saih, k. Segawa, Appl. Catal., A: Gen. 353, 258, (2009).

2. J. Ojeda, N. Escalona, J.M. Palacios, M. Yates, J.L.G. Fierro, A. López Agudo, F.J. Gil-Llambías, Appl. Catal. A: Gen. 350, 6, (2008).

3. Hrabar, J. Hein, O. Y. Gutiérrez, J. A. Lercher, J. Catal. 281, 325, (2011).

4. G. Li, Y. Liu, Z. Tang, C. Liu, Appl. Catal. A: Gen. 437, 79, (2012).

5. A. Infantes-Molina, A. Romero-Pérez, E. Finocchio , G. Busca , A. Jiménez-López ,E. Rodríguez-Castellón, J. Catal. 305, 101, (2013).

6. R.H. Bowker, B. Ilic, B. A. Carrillo, M. A. Reynolds, ,B. D. Murray, M. E. Bussell, Appl. Catal. A: Gen. 482, 221, (2014).

7. M. Egorova, R. Prins, J. Catal. 221, 17, (2004).

8. M. Vrinat, R. Bacaud, D. Laurenti, M. Cattenot, N. Escalona, S. Gamez, Catal. Today 107, 570, (2005).

9. H. Farag, M. Kishida, H. Al-Megren, Appl. Catal. A: Gen. 469, 173, (2014).

10. G.C. Laredo, J. A De los Reyes, J. L. Cano D, J. J. Castillo, Appl. Catal. A: Gen. 207, 103, (2001).
11. G. Deepa, T.M. Sankaranarayanan, K. Shanthi, B. Viswanathan, Catal. Today 198,252, (2012).

12. O. Y. Gutiérrez, A. Hrabar, J. Hein, Y. Yu, J. Han, J. A. Lercher, J. Catal. 295, 155, (2012).

13. L. Li-hua, L. Shu-qun, C. Yong-ming, L. Yun-qi, L. Chen-guang, J. Fuel Chem. Technol. 41, 698, (2013).

14. M.Sun, A. E. Nelson, J. Adjaye, J. Catal. 231, 223, (2005).

15. H. A. Al-Megren, S. L. Gonzáles-Cortés, T. Xiao, M. L.H. Green, Appl. Catal. A: Gen. 329, 36, (2007).

16. C.S. Raghuveer, J.W. Thybaut, R. De Bruycker, K. Metaxas, T. Bera, G.B. Marin, Fuel 125, 206, (2014).

17. F. Valdevenito, R. García, N. Escalona, F.J. Gil-Llambias, S.B. Rasmussen , A. López-Agudo, Catal. Commun. 11, 1154, (2010).

18. P. Baeza, M.S. Ureta-Za nartu, N. Escalona, J. Ojeda, F.J. Gil-Llambías, B. Delmon, Appl. Catal. A: Gen. 274, 303, (2004).

19. P. Baeza, M. Villarroel, P. Ávila, A. López Agudo, B. Delmon, F.J. Gil Llambías, Appl. Catal. A: Gen. 304, 109, (2006).

20. M. Villarroel, P. Baeza, N. Escalona, J. Ojeda, B. Delmon, F.J. Gil Llambías, Appl. Catal. A: Gen. 345, 152, (2008).

21. M. Villarroel, P. Baeza, F. Gracia, N. Escalona, P. Ávila, F.J. Gil Llambías, Appl. Catal. A: Gen. 364, 75, (2009).

22. M. Villarroel, A. Méndez, G. Águila, N. Escalona, P. Baeza, F. GilLlambías, Catal. Today 156, 65, (2010).

23. M. Villarroel, E. Camú, N. Escalona, P. Ávila, S.B. Rasmussen, P. Baeza, F. Gil-Llambías, Appl. Catal. A: Gen. 399, 63, (2011).

24. J. Ojeda, N. Escalona, P. Baeza, M. Escudey, F.J. Gil-Llambías, Chem. Commun. 13, 1608, (2003).

25. KG.Mc. llvried, Bid. Eng. Chem. Process.Des.Dey.10, 125, (1971).

26. J.A. Anabtawi, R.S. Mann, K.C. Khulbe, J. Catal. 63, 459, (1980).

27. A. Méndez, M. Villarroel, F.J. Gil-Llambías, P. Ávila, P. Baeza "Hidrodesulfuración utilizando lechos apilados de Re(W)//Ni-Re: Enfoque hacia una Hidrodesulfuración profunda”, CICAT, Argentina (2012).

28. R. Cid, G. Pechi, Appl. Catal. 14, 15, (1985).

29. S. Kozai, H. Kabashima, H. Hattori, Fuel 79, 305, (2000). 